\title{
Limonoids from the Root of Dictamnus radicis Cortex
}

\author{
Pei Hua Zhao, Li Mei Sun, Xiu Jin Liu, Mei Ai CaO, and Cheng Shan Yuan* \\ State Key Laboratory of Applied Organic Chemistry, College of Chemistry and Chemical Engineering, Lanzhou \\ University; Lanzhou 730000, P. R. China. Received August 16, 2007; accepted October 3, 2007
}

\begin{abstract}
Chemical investigation of the roots of Dictamnus radicis Cortex led to the isolation of a new limonoid isodictamdiol (1) and a known dictamdiol (2), the first 5S/9S-type degraded limonoids, together with other six known limonoids (3-8). The chemical structures were identified on the basis of modern spectroscopic methods, including IR, MS, NMR $\left({ }^{1} \mathrm{H}-\mathrm{NMR},{ }^{13} \mathrm{C}-\mathrm{NMR},{ }^{1} \mathrm{H}-{ }^{1} \mathrm{H}\right.$ COSY, HMQC, HMBC, NOESY). Additionally, the absolute configurations of limonoid isodictamdiol (1) and dictamdiol (2) were separately elucidated by single crystal X-ray diffraction, as well as their circular dichroism spectra. Furthermore, all compounds were evaluated for antibacterial activity against three bacterial cultures.
\end{abstract}

Key words Dictamnus radicis Cortex; isodictamdiol; absolute configuration; antibacterial activity

Dictamnus radicis Cortex is a traditional folk herb belonging to Rutaceae. Its dried roots have been called the Chinese drug, Bai-Xian-Pi, which has been used for the treatment of jaundice, rheumatism and various other diseases. ${ }^{1)}$ Previously phytochemical studies on the species revealed the presence of limonoids, ${ }^{2-8)}$ furoquinoline alkaloids, ${ }^{9,10)}$ trinorguaianetype sesquiterpenes, ${ }^{11)}$ and flavonoids. ${ }^{12)}$

During our study on limonoid constituents from $D$. radicis Cortex, a pair of diastereomers named isodictamdiol (1) and dictamdiol (2), the first 5S/9S-type degraded limonoids, were isolated. ${ }^{2)}$ Six known limonoids, fraxinellone (3), ${ }^{3,4)}$ fraxinellonone (4), ${ }^{5)}$ evodol (5), ${ }^{7)}$ rutaevine (6), ${ }^{7)}$ limonin (7), ${ }^{7)}$ and obacunone $(\mathbf{8})^{7,8)}$ were also isolated during this study. Among the eight isolated compounds, isodictamdiol (1) had a new structure. In addition, the spectroscopic data of dictamdiol (2) were re-assigned and the absolute configurations were elucidated for the first time.

\section{Results and Discussion}

Isodictamdiol $(\mathbf{1}),[\alpha]_{\mathrm{D}}^{20}-22^{\circ}(c=0.57 \mathrm{MeOH})$, was obtained as colorless crystals. Its IR absorptions exhibited the existence of two hydroxyl groups $\left(3362,3259 \mathrm{~cm}^{-1}\right)$, a $\delta$-lactone $\left(1724 \mathrm{~cm}^{-1}\right)$, a double bond $\left(1560 \mathrm{~cm}^{-1}\right)$, and a furanyl ring $\left(1506,873 \mathrm{~cm}^{-1}\right)$. The molecular formula was deduced to be $\mathrm{C}_{15} \mathrm{H}_{18} \mathrm{O}_{5}$ from HR-ESI-MS $\left(\left[\mathrm{M}+\mathrm{NH}_{4}\right]^{+} \mathrm{m} / z\right.$ 296.1488, Calcd 296.1492) with seven degrees of unsaturation. Analysis of the proton and carbon NMR spectra of $\mathbf{1}$ indicated the presence of a $\beta$-substituted furanyl ring $\left[\delta_{\mathrm{H}} 7.65,7.59,6.53\right.$ (each brs, $1 \mathrm{H}), \delta_{\mathrm{C}} 110.9(\mathrm{CH}), 121.4(\mathrm{C}), 142.3(\mathrm{CH})$, and $144.0(\mathrm{CH})]$, a tertiary methyl $\left[\delta_{\mathrm{H}} 1.02(\mathrm{~s}, 3 \mathrm{H})\right]$, a vinyl methyl $\left[\delta_{\mathrm{H}} 1.86(\mathrm{~s}, 3 \mathrm{H})\right]$, two oxygen-bearing methines $\left[\delta_{\mathrm{H}}\right.$ $4.02($ br s, $\left.1 \mathrm{H}), \delta_{\mathrm{H}} 4.82(\mathrm{~d}, 1 \mathrm{H}, J=4.8 \mathrm{~Hz})\right]$, two secondary hydroxyl groups $\left[\delta_{\mathrm{H}} 4.02(\mathrm{brs}, 1 \mathrm{H})\right.$ and $\delta_{\mathrm{H}} 5.33(\mathrm{~d}, 1 \mathrm{H}$, $J=4.8 \mathrm{~Hz}$ )], one ester carbonyl group, and one tetrasubstituted double bond (Table 1). The assignments of all the direct ${ }^{1} \mathrm{H}-{ }^{13} \mathrm{C}$ bondings were made on the basis of the heteronuclear multiple quantum coherence (HMQC) spectrum and the planar structure was determined by ${ }^{1} \mathrm{H}-{ }^{1} \mathrm{H}$ correlation spectroscopy $\left({ }^{1} \mathrm{H}-{ }^{1} \mathrm{H}\right.$ COSY $)$. The heteronuclear multiple bond correlations (HMBC) were determined as follows: H-14/C-1, 2, 6; H-15/C-4, 5, 6, 9; H-9/C-10, 11, 13; H-7/C-1, 5, 6, 8; 2$\mathrm{OH} / \mathrm{C}-2$, and $7-\mathrm{OH} / \mathrm{C}-7$. The cross-peaks observed in the NOESY experiments between the protons $\mathrm{H}-9 / \mathrm{H}-4 b, \mathrm{H}-$ $4 b / \mathrm{H}-3 b, \mathrm{H}-3 b / \mathrm{H}-2$, and $\mathrm{H}-2 / \mathrm{H}-4 b$ indicated that $\mathrm{H}-2$ and $\mathrm{H}-$
9 were on the same side and were arbitrarily assigned $\beta$-orientations while the 2-OH and furanyl ring were in $\alpha$-configurations. Meanwhile, the large coupling constant between $\mathrm{H}-2$ and $\mathrm{H}-3 \mathrm{a}\left[J_{2,3 \mathrm{a}}=9.2 \mathrm{~Hz}\right.$, (the peak of $\mathrm{H}-2$ was split after adding $\mathrm{D}_{2} \mathrm{O}$ in the $\mathrm{HMBC}$ experiments)] also implied that $\mathrm{H}$ 2 should be axial (in $\beta$-orientation). The NOESY correlation pairs of H-15/H-3a, and H-15/H-4a suggested that H-15 had an $\alpha$-orientation (Fig. 1). Although the stereochemistry at C7 could not be determined by analysis of the available spectral data since the splitting pattern and relevant NOESY correlations did not provide sufficient information, fortunately, we obtained a single crystal (petroleum ether-acetone $1: 1$ ) and X-ray crystallography (Fig. 2) showed that the 7-OH was in the $\beta$-configuration. Furthermore, the single crystal X-ray diffraction for 1 showed that the $\delta$-lactone ring was in a boat conformation (H-9 and 7-OH were cis, and $\mathrm{H}-9$ was axial), which corresponded to the peak centered at $\lambda_{\max } 222 \mathrm{~nm}$ in the CD spectrum. ${ }^{14)}$ According to the Klyne sector rule for the saturated lactone, ${ }^{15)}$ the positive Cotton effect, $[\theta]_{222}=+110000$, indicated that the absolute configuration at C-5 was assigned to $S$. Then $\mathrm{C}-2, \mathrm{C}-7$, and C-9 were fixed to be $S, R$, and $S$, respectively. Therefore, the structure of $\mathbf{1}$ was

Table 1. ${ }^{1} \mathrm{H}$ - and ${ }^{13} \mathrm{C}-\mathrm{NMR}$ Spectral Data for Compound $\mathbf{1}\left(\mathrm{CD}_{3} \mathrm{COCD}_{3}, \delta\right.$ in ppm, $J$ in $\mathrm{Hz}$ )

\begin{tabular}{clrccr}
\hline \hline Position & \multicolumn{1}{c}{$\delta_{\mathrm{H}}$} & $\delta_{\mathrm{C}}$ & Position & \multicolumn{1}{c}{$\delta_{\mathrm{H}}$} & \multicolumn{1}{c}{$\delta_{\mathrm{C}}$} \\
\hline 1 & & $139.5 \mathrm{~s}$ & 9 & $5.51 \mathrm{~s}$ & $79.7 \mathrm{~d}$ \\
2 & $4.02 \mathrm{br} \mathrm{s}$ & $70.2 \mathrm{~d}$ & 10 & & $121.4 \mathrm{~s}$ \\
$3 \mathrm{a}$ & $1.76 \mathrm{~m}$ & $28.9 \mathrm{t}$ & 11 & $7.65 \mathrm{br} \mathrm{s}$ & $142.3 \mathrm{~d}$ \\
$3 \mathrm{~b}$ & $2.05 \mathrm{~m}$ & & 12 & $7.59 \mathrm{br} \mathrm{s}$ & $144.0 \mathrm{~d}$ \\
$4 \mathrm{a}$ & $1.14 \mathrm{dt}(13.2,3.2)$ & $32.4 \mathrm{t}$ & 13 & $6.53 \mathrm{br} \mathrm{s}$ & $110.9 \mathrm{~d}$ \\
$4 \mathrm{~b}$ & $1.54 \mathrm{ddd}(14.0,13.2,3.2)$ & & 14 & $1.86 \mathrm{~s}$ & $14.6 \mathrm{q}$ \\
5 & & $40.0 \mathrm{~s}$ & 15 & $1.02 \mathrm{~s}$ & $18.9 \mathrm{q}$ \\
6 & & $135.1 \mathrm{~s}$ & $2-\mathrm{OH}$ & $4.02 \mathrm{br} \mathrm{s}$ & \\
7 & $4.82 \mathrm{~d}(4.8)$ & $67.9 \mathrm{~d}$ & $7-\mathrm{OH}$ & $5.33 \mathrm{~d}(4.8)$ & \\
8 & & $171.1 \mathrm{~s}$ & & &
\end{tabular}

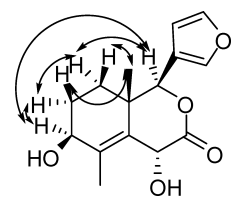

Fig. 1. Key NOESY Correlations of Compound 1 

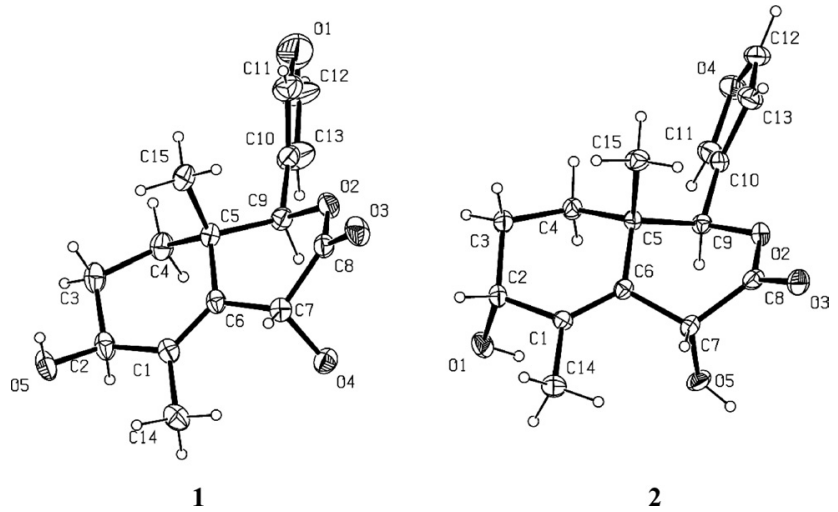

Fig. 2. X-Ray Structures of $\mathbf{1}$ and 2
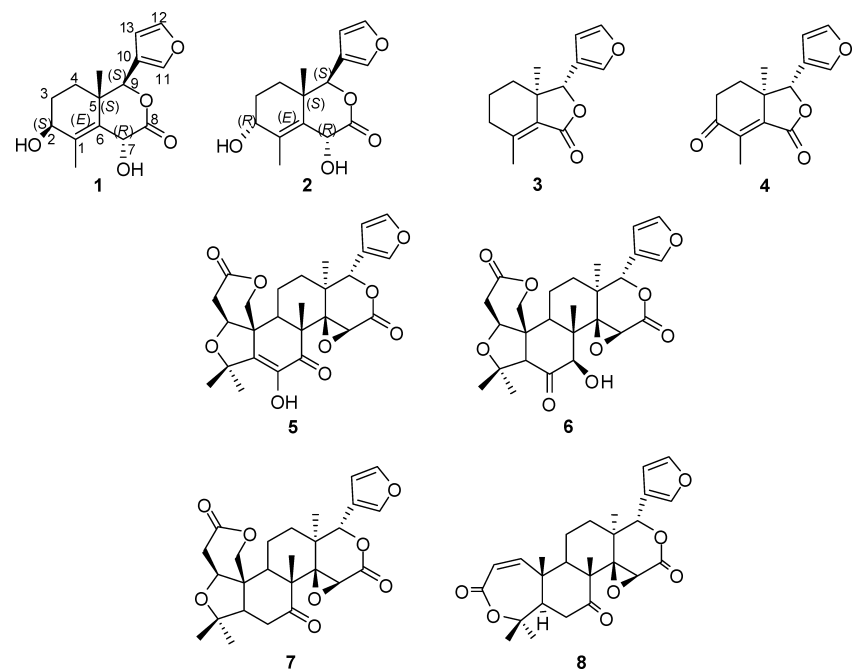

Fig. 3. The Structures of Compounds $\mathbf{1}-\mathbf{8}$

assigned as shown in Fig. 3.

Dictamdiol (2), $[\alpha]_{\mathrm{D}}^{20}-114^{\circ}(c=0.42 \mathrm{MeOH})$ and colorless crystals, showed a molecular formula of $\mathrm{C}_{15} \mathrm{H}_{18} \mathrm{O}_{5}$ as determined by HR-ESI-MS $\left([\mathrm{M}+\mathrm{Na}]^{+}\right.$at $\mathrm{m} / \mathrm{z} 301.1048$, Calcd 301.1046) with seven degrees of unsaturation. The IR spectrum exhibited absorptions for two hydroxyl groups $\left(3422,3342 \mathrm{~cm}^{-1}\right)$, a $\delta$-lactone $\left(1732 \mathrm{~cm}^{-1}\right)$, a double bond $\left(1592 \mathrm{~cm}^{-1}\right)$, and a furanyl ring $\left(1503,876 \mathrm{~cm}^{-1}\right)$. This compound gave the same $[\mathrm{M}]^{+}$and fragment peaks in the EI-MS, and had similar features in the ${ }^{1} \mathrm{H}$ - and ${ }^{13} \mathrm{C}$-NMR spectra to those of $\mathbf{1}$ (Table 1). In comparison with the NMR data of $\mathbf{1}$, the $\mathrm{H}-2$ and 2-OH proton signals of $\mathbf{2}$ exhibited an upfield shift from $\delta 4.02$ to $\delta 3.90$ and a downfield shift from $\delta 4.02$ to $\delta 4.13$, respectively. The signal of $\mathrm{C}-2$ in the ${ }^{13} \mathrm{C}$ spectrum was shifted upfield from $\delta 70.2$ to $\delta 67.7$, and the signal at C-14 was shifted downfield from $\delta 14.6$ to $\delta 17.1$, indicating that the stereochemistry at $\mathrm{C}-2$ in $\mathbf{2}$ and $\mathbf{1}$ was different. From the ${ }^{1} \mathrm{H}-\mathrm{NMR}$ coupling constants, H-2 should be equatorial because of the small coupling constant between $\mathrm{H}-2$ and $\mathrm{H}-3 \mathrm{~b}\left(J_{2,3 \mathrm{~b}}=4.8 \mathrm{~Hz}\right)$. To sum up above deduction, 2 was elucidated to be dictamdiol which was previously isolated from $D$. angustifolius ${ }^{2)}$ and $D$. dasycarpus ${ }^{13)}$ separately. The spectra of compound 2 were assigned in the lit. 2, and the spectroscopic data were re-assigned in the ref. 13 on the basis of 2D-NMR experiments, but the assignment for chem-
Table 2. ${ }^{1} \mathrm{H}$ - and ${ }^{13} \mathrm{C}-\mathrm{NMR}$ Assignment for Compound $\mathbf{2}(\delta$ in ppm, $J$ in $\mathrm{Hz})$

\begin{tabular}{clrrr}
\hline \hline Position & \multicolumn{1}{c}{$\delta_{\mathrm{H}}{ }^{a}$} & \multicolumn{1}{c}{$\delta_{\mathrm{C}}{ }^{a)}$} & $\left.\delta_{\mathrm{C}}{ }^{b}\right)$ & $\left.\delta_{\mathrm{C}}{ }^{c}\right)$ \\
\hline 1 & & $137.4 \mathrm{~s}$ & 136.0 & 135.6 \\
2 & $3.90 \mathrm{t}(4.8)$ & $67.7 \mathrm{~d}$ & 65.8 & 68.0 \\
$3 \mathrm{a}$ & $1.78-1.71 \mathrm{~m}$ & $27.8 \mathrm{t}$ & 27.1 & 26.9 \\
$3 \mathrm{~b}$ & $1.96 \mathrm{tt}(12.8,3.2)$ & & & \\
$4 \mathrm{a}$ & $0.96 \mathrm{dt}(12.8,3.2)$ & $28.0 \mathrm{t}$ & 26.9 & 26.9 \\
$4 \mathrm{~b}$ & $1.71-1.64 \mathrm{~m}$ & & & \\
5 & & $40.0 \mathrm{~s}$ & 38.8 & 39.2 \\
6 & & $136.0 \mathrm{~s}$ & 134.3 & 136.7 \\
7 & $4.81 \mathrm{~d}(5.2)$ & $67.6 \mathrm{~d}$ & 65.9 & 66.7 \\
8 & & $171.1 \mathrm{~s}$ & 170.8 & 170.9 \\
9 & $5.48 \mathrm{~s}$ & $121.7 \mathrm{~d}$ & 78.4 & 79.8 \\
10 & & $142.2 \mathrm{~d}$ & 141.5 & 120.0 \\
11 & $7.64 \mathrm{br} \mathrm{s}$ & $144.0 \mathrm{~d}$ & 143.4 & 141.9 \\
12 & $7.58 \mathrm{br} \mathrm{s}$ & $110.9 \mathrm{~d}$ & 120.3 & 109.9 \\
13 & $6.52 \mathrm{br} \mathrm{s}$ & $17.1 \mathrm{q}$ & 17.0 & 17.0 \\
14 & $1.89 \mathrm{~s}$ & $17.5 \mathrm{q}$ & 16.6 & 17.2 \\
15 & $0.92 \mathrm{~s}$ & & & \\
$2-\mathrm{OH}$ & $4.13 \mathrm{br} \mathrm{s}$ & & & \\
$7-\mathrm{OH}$ & $5.36 \mathrm{~d}(5.2)$ & & & \\
& & & &
\end{tabular}

a) The data were measured in $\mathrm{CD}_{3} \mathrm{COCD}_{3}$. b) The data in ref. 13. c) The data in ref. 2 .

Table 3. Antibacterial Activities of Compounds $\mathbf{1}-\mathbf{8}^{a, b)}$

\begin{tabular}{cccc}
\hline \hline Compounds & $\begin{array}{c}\text { Staphylococcus } \\
\text { aureus }\end{array}$ & $\begin{array}{c}\text { Escherichia } \\
\text { coli }\end{array}$ & $\begin{array}{c}\text { Bacillus } \\
\text { subtilis }\end{array}$ \\
\hline $\mathbf{1}$ & - & - & + \\
$\mathbf{2}$ & - & - & - \\
$\mathbf{3}$ & - & - & - \\
$\mathbf{4}$ & - & + & - \\
$\mathbf{5}$ & - & - & + \\
$\mathbf{6}$ & - & - & - \\
$\mathbf{7}$ & + & - & - \\
$\mathbf{8}$ & - & +++ & +++ \\
Chloramphenicol & +++ & - & - \\
$\mathrm{H}_{2} \mathrm{O}$ & - & &
\end{tabular}

a) Zone diameter of growth inhibition: $<10 \mathrm{~mm}(-), 10-12 \mathrm{~mm}(+), 13-15 \mathrm{~mm}$ $(++)$, and $16-20 \mathrm{~mm}(+++)$. b) Each tested compound as well as chloramphenicol was $0.2 \mathrm{ml}$ of $100 \mathrm{mg} \cdot \mathrm{ml}^{-1}$.

ical shifts of $\mathrm{C}-10$ and $\mathrm{C}-13(\delta 110.1,120.3)$ were still found to be incorrect in ref. 13 , and ${ }^{13} \mathrm{C}-\mathrm{NMR}$ were definitely re-assigned again to be $(\delta 121.7,110.9)$ in this manuscript (Table $2)$. Additionally, the reported specific rotation ${ }^{2}$ was of the same sign $\left\{[\alpha]_{\mathrm{D}}^{20}-151^{\circ}(c=0.1 \mathrm{MeOH})\right\}$ but somewhat higher than that measured for our sample $\left\{[\alpha]_{\mathrm{D}}^{20}-114^{\circ}\right.$ $(c=0.42 \mathrm{MeOH})\}$. The single crystal X-ray diffraction (Fig. 2) showed that the $\delta$-lactone ring for $\mathbf{2}$ was also in boat conformation, which corresponded to the $\lambda_{\max } 223 \mathrm{~nm}$ in the $\mathrm{CD}$ spectra, just as that in the spectrum of compound 1 . Thus, the stereochemistry of C-2, C-5, C-7, and C-9 were fixed to be $R$, $S, R$, and $S$, respectively. The structure of $\mathbf{2}$ was determined and named $(2 R, 5 S, 7 R, 9 S)$-dictamdiol (Fig. 3).

To the best of our knowledge, the absolute configurations at C-5 and C-9 as $S$ and $S$ of the limonoids were reported for the first time.

The known compounds, $\mathbf{3}-\mathbf{8}$, were determined as fraxinellone $(\mathbf{3}),{ }^{3,4)}$ fraxinellonone $(4),{ }^{5)}$ evodol $(5),{ }^{7)}$ rutaevine $(6),{ }^{7)}$ limonin $(7),{ }^{7}$ and obacunone $(8)^{7,8)}$ by comparison of their spectral data with those reported. 
The antimicrobial activities of compounds $\mathbf{1}-\mathbf{8}$ were tested. Among them, compounds 1, 4 and 7 exhibited weak antibacterial activities against Bacillus subtilis, Escherichia coli and Staphylococcus aureus, respectively (Table 3).

\section{Experimental}

General Experimental Procedures Melting points were determined on a SWG X-4 melting point apparatus and were uncorrected. Optical rotations were measured on a Perkin-Elmer 341 polarimeter. IR spectra were measured on a Nicolet 170SX FT-IR instrument (neat). One-dimensional (1D) and two-dimensional (2D) NMR spectra were measured on a Varian Mercury-400BB NMR spectrometer with TMS as the internal standard. Electron impact ionization mass spectrometry (EI-MS) data were taken on VG ZABHS mass spectrometer at $70 \mathrm{eV}$. HR-ESI-MS were recorded on a Bruker APEX II. UV spectra were obtained using a Shimadzu UV-260 spectrophotometer. Single crystal X-ray diffraction was measured on a D8 SMART APEX II X-ray single crystal instrument. The CD spectra were recorded on an OLIS DSM 1000 bisbeam CD spectrometer. Silica gel (200-300 mesh) used for column chromatography, and silica $\mathrm{GF}_{254}(10-40 \mu)$ for TLC were supplied by the Qing-dao, Marine Chemical Factory, Qingdao, P. R. China. TLC spots were detected under a UV lamp or by heating after being sprayed with $5 \% \mathrm{H}_{2} \mathrm{SO}_{4}$ in $\mathrm{EtOH}(\mathrm{v} / \mathrm{v})$.

Plant Material The roots of Dictamnus radicis Cortex were purchased from Focitang Medicine Material Corporation in Lanzhou, and identified by Prof. Peijun Yu, of the Second Hospital of Lanzhou University. A voucher specimen (No. 20050301) was deposited in the Institute of Organic Chemistry, Lanzhou University.

Extraction and Separation The dried and powdered underground parts of $D$. radicis Cortex $(10.0 \mathrm{~kg})$ was percolated three times with petroleum ether-EtOAc-MeOH $(1: 1: 1,3 \times 201)$ at room temperature. After evaporated to dryness under reduced pressure, a residue $(366.4 \mathrm{~g})$ was obtained and redissolved in water $(600 \mathrm{ml})$. The aqueous solution was extracted with petroleum ether $\left(30-60{ }^{\circ} \mathrm{C}, 600 \mathrm{ml} \times 3\right)$, EtOAc $(600 \mathrm{ml} \times 3)$ and $n-\mathrm{BuOH}$ $(600 \mathrm{ml} \times 3)$ to give extracts $50.5 \mathrm{~g}, 101.0 \mathrm{~g}$ and $56.3 \mathrm{~g}$, respectively. The EtOAc extracts were subjected to column chromatography on silica gel and eluted with $\mathrm{CHCl}_{3}-\mathrm{MeOH}(1: 99-50: 50 \mathrm{v} / \mathrm{v})$ to give fractions $\mathrm{A}-\mathrm{F}$. Fractions $\mathrm{A}, \mathrm{B}$, and $\mathrm{C}$ were separated by sequential column chromatography on silica gel and then purified by Sephadex $\mathrm{LH}-20$ column $\left(\mathrm{CHCl}_{3}-\mathrm{MeOH} 2: 1\right.$ $\mathrm{v} / \mathrm{v})$ and preparative TLC to afford $3(696 \mathrm{mg}), 4(7 \mathrm{mg}), 5(8 \mathrm{mg}), 6$ $(10 \mathrm{mg}), 7(456 \mathrm{mg})$, and $\mathbf{8}(816 \mathrm{mg})$. Fraction D was chromatographed over repeated silica gel column chromatography and Sephadex LH-20 column $\left(\mathrm{CHCl}_{3}-\mathrm{MeOH} 2: 1 \mathrm{v} / \mathrm{v}\right)$ and was recrystallized with petroleum ether-acetone $(1: 1)$ to give $\mathbf{1}(47 \mathrm{mg})$ and $\mathbf{2}(51 \mathrm{mg})$.

Isodictamdiol (1): $\mathrm{C}_{15} \mathrm{H}_{18} \mathrm{O}_{5}$, colorless rhomboid crystals, mp 174 $176^{\circ} \mathrm{C}$. $[\alpha]_{\mathrm{D}}^{20}-22^{\circ}(c=0.57 \mathrm{MeOH}) . \mathrm{CD}(\mathrm{MeOH})[\theta]_{222}=+110000 . \mathrm{IR}$ (KBr): $3362,3259,1724,1560,1506,1021,873$, and $800 \mathrm{~cm}^{-1}$. EI-MS $\mathrm{m} / \mathrm{z}$ $278[\mathrm{M}]^{+}(0.49), 260$ (0.51), 152 (24.7), 136 (100), 121 (24.7), 93 (33.8) HR-ESI-MS $m / z$ : $296.1488\left[\mathrm{M}+\mathrm{NH}_{4}\right]^{+}$(Calcd for 296.1492). ${ }^{1} \mathrm{H}-$ and ${ }^{13} \mathrm{C}-$ NMR: see Table 1.

Dictamdiol (2): $\mathrm{C}_{15} \mathrm{H}_{18} \mathrm{O}_{5}$, colorless rhomboid crystals, mp $148-150{ }^{\circ} \mathrm{C}$. $[\alpha]_{\mathrm{D}}^{20}-114^{\circ}(c=0.42 \mathrm{MeOH}) . \mathrm{CD}(\mathrm{MeOH})[\theta]_{223}=+12500$. IR $(\mathrm{KBr})$ $3422,3342,1732,1592,1503$, and $876 \mathrm{~cm}^{-1}$. EI-MS $\mathrm{m} / z: 278[\mathrm{M}]^{+}(0.9)$, 260 (0.02), 136 (100), 121 (26.0), 93 (35.0). HR-ESI-MS m/z: 301.1048 $[\mathrm{M}+\mathrm{Na}]^{+}\left(\mathrm{Calcd}\right.$ for 301.1046). ${ }^{1} \mathrm{H}-$ and ${ }^{13} \mathrm{C}-\mathrm{NMR}$ : see Table 2.

$\mathrm{X}$-Ray Crystallography of Isodictamdiol (1): Colorless crystal $(0.06 \times 0.31 \times 0.44 \mathrm{~mm})$ grown from petroleum ether-acetone, $\mathrm{C}_{15} \mathrm{H}_{18} \mathrm{O}_{5}$, $\mathrm{Mw}=278.29$, monoclinic, space group $P 2(1), \quad Z=4, \quad a=7.5269(5)$, $b=10.5031(7), c=18.8455(12) \AA, \alpha=90.00^{\circ}, \quad \beta=97.971(3)^{\circ}, \quad \gamma=90.00^{\circ}$,
$V=1475.45(17) \AA^{3}, \mathrm{dc}=1.253 \mathrm{~g} \cdot \mathrm{cm}^{-3}, \mathrm{~F}(000)=592, \lambda(\mathrm{MoK} \alpha)=0.7107 \AA$, $\mu=0.094 \mathrm{~mm}^{-1} ; 8974$ measured intensities $(-9 \leq h \leq 9,-13 \leq k \leq 9$, $-24 \leq I \leq 24), 4697$ unique $\left(R_{\mathrm{int}}=0.0351\right)$ of which 2995 observed with $I \geq 2.0 \sigma(I)$.

X-Ray Crystallography of Dictamdiol (2): Colorless crystal $(0.20 \times$ $0.21 \times 0.23 \mathrm{~mm}$ ) grown from petroleum ether-acetone, $\mathrm{C}_{15} \mathrm{H}_{18} \mathrm{O}_{5} \cdot \mathrm{H}_{2} \mathrm{O}$, $\mathrm{Mw}=296.31$, monoclinic, space group $P 2(1), Z=4, \quad a=11.0906(6)$, $b=9.1801(5), c=15.5766(8) \AA, \alpha=90.00^{\circ}, \beta=109.752(3)^{\circ}, \gamma=90.00^{\circ}, V=$ $1492.59(14) \AA^{3}, \mathrm{dc}=1.319 \mathrm{~g} \cdot \mathrm{cm}^{-3}, \mathrm{~F}(000)=632, \lambda \quad(\mathrm{MoK} \alpha)=0.7107 \AA$, $\mu=0.102 \mathrm{~mm}^{-1} ; 8062$ measured intensities $(-13 \leq h \leq 13,-8 \leq k \leq 11$, $-18 \leq I \leq 15), 5037$ unique $\left(R_{\text {int }}=0.0298\right)$ of which 3816 observed with $I \geq 2.0 \sigma(I)$

Antibacterial Assays The antibacterial screening was carried out by employing the cup-plate method. Three strains of bacteria (Staphylococcus aureus, Escherichia coli, and Bacillus subtilis) were incubated in beef broth and incubated at $37^{\circ} \mathrm{C}$ for $24 \mathrm{~h}$. After dilution of beef broth, with three microorganisms were cultured in agar medium dishes, respectively; four cups $(8 \times 10 \mathrm{~mm})$ were put onto the dishes, and each tested compound $(0.2 \mathrm{ml}$ of $100 \mathrm{mg} / \mathrm{ml}$ ) was added into the cups under aseptic conditions. Then the dishes were incubated at $37^{\circ} \mathrm{C}$ for $24 \mathrm{~h}$. The zone of inhibition of the growth of bacteria, which were produced by diffusion of the compounds from the cup into the surrounding medium, was measured to evaluate the antibacterial activity. Each experiment was repeated twice. Chloramphenicol was used as a positive control for all experiments.

Acknowledgements This work was supported by National Basic Research Program of China (2007CB108903) and the National Natural Science Foundation of China (No. 20621091 QT Program). We also thank Dr. William Paquette (Department of Chemistry, University of Pittsburgh) and Dr. Jingbo Xiao (Department of Pharmaceutical Sciences, University of Pittsburgh) for checking the manuscript.

\section{References}

1) Jiangsu New Medical College (Ed.), "Dictionary of Chinese Traditional Medicine," Shanghai Science and Technology Press, Shanghai, 1968, p. 737.

2) Hu C. Q., Han J. W., Zhao J. G., Song G. Q., Li Y. H., Yin D. X., Acta Botanica Sinica, 31, 453-458 (1989).

3) Blaise A. J., Winternitz F., Phytochemistry, 24, 2379-2381 (1985).

4) Liu Z. L., Xu Y. J., Wu J., Goh S. H., Ho S. H., J. Agri. Food. Chem., 50, 1447-1450 (2002).

5) Boustie J., Moulis C., Gleye J., Fouraste I., Servin P., Bon M., Phytochemistry, 29, 1699-1701 (1990).

6) Nakatani M., Takao H., Iwashita T., Naoki H., Hase T., Phytochemistry, 27, 1429-1432 (1988).

7) Sugimoto T., Miyase T., Kuroyanagi M., Ueno A., Chem. Pharm. Bull., 36, 4453-4461 (1988)

8) Rugutt J. K., Fischer N. H., Nauman M. A., Schmidt T. J., Berner D. K., Spectroscopy Lett., 29, 711-726 (1996)

9) Kanamori H., Sakamoto I., Mizuta M. Chem. Pharm. Bull., 34, 1826-1829 (1986).

10) Storer R., Young D. W., Tetrahedron, 29, 1217-1222 (1973).

11) Takeuchi N., Fujita T., Goto K., Morisaki N., Osone N., Tobinaga S., Chem. Pharm. Bull., 41, 923-925 (1993).

12) Souleles C., J. Nat. Prod., 52, 1311-1312 (1989).

13) Jiang Y., Tu P. F., Zhang N., Bopuxue Zazhi, 23, 327-332 (2006).

14) Wolf H., Tetrahedron Lett., 42, 5151—5156 (1966)

15) Snatzke G., Ripperger H., Horstmann C., Schreiber K., Tetrahedron, 22, 3103-3116 (1966) 